\title{
Validation of the concept Risk for Decreased Cardiac Output
}

\author{
Eduarda Ribeiro dos Santos ${ }^{1}$ \\ Mariana Fernandes de Souza ${ }^{2}$ \\ Maria Gaby Rivero de Gutiérrez ${ }^{3}$ \\ Vera Lucia Regina Maria ${ }^{4}$ \\ Alba Lucia Bottura Leite de Barros ${ }^{2}$
}

\begin{abstract}
Objectives: to validate the concept "risk for decreased cardiac output". Method: Six of the eight steps suggested in the technique developed by Walker \& Avant were adopted to analyze the concept of the phenomenon under study and the proposal made by Hoskins was used for content validation, taking into account agreement achieved among five experts. Results: the concept "decreased cardiac output" was found in the nursing and medical fields and refers to the heart's pumping capacity while the concept "risk" is found in a large number of disciplines. In regard to the defining attributes, "impaired pumping capacity" was the main attribute of decreased cardiac output and "probability" was the main attribute of risk. The uses and defining attributes of the concepts "decreased cardiac output" and "risk" were analyzed as well as their antecedent and consequent events in order to establish the definition of "risk for decreased cardiac output", which was validated by $100 \%$ of the experts. Conclusion: The obtained data indicate that the risk for decreased cardiac output phenomenon can be a nursing diagnosis and refining it can contribute to the advancement of nursing classifications in this context.
\end{abstract}

Descriptors: Nursing Diagnosis; Cardiac Output; Risk; Concept Formation.

${ }^{1}$ Doctoral student, Escola Paulista de Enfermagem, Universidade Federal de São Paulo, Brazil.

2 PhD, Full Professor, Escola Paulista de Enfermagem, Universidade Federal de São Paulo, Brazil.

${ }^{3}$ PhD, Associate Professor, Escola Paulista de Enfermagem, Universidade Federal de São Paulo, Brazil.

${ }^{4} \mathrm{RN}, \mathrm{PhD}$.

Corresponding Author:

Alba Lucia Bottura Leite de Barros

Universidade Federal de São Paulo, Escola Paulista de Enfermagem

Rua Napoleão de Barros, 754, $2^{\circ}$ andar

Vila Clementino

CEP: 04024-002, São Paulo, SP, Brasil

E-mail: barros.alba@unifesp.br 


\section{Validação do conceito risco de débito cardíaco diminuído}

Objetivo: validar o conceito de risco de débito cardíaco diminuído. Método: foi adotada a técnica de Walker \& Avant para a análise do conceito do fenômeno em foco, com utilização de seis das oito etapas sugeridas, e da proposta de Hoskins para validação de conteúdo, considerando-se a concordância entre cinco especialistas. Resultados: o conceito de débito cardíaco diminuído foi encontrado nas áreas de enfermagem e médica e está centrado na capacidade de bombeamento do coração, embora também esteja presente em um grande número de disciplinas. Em relação aos atributos definidores, o débito cardíaco diminuído teve como atributo principal a deficiência de bombeamento cardíaco e o risco, o atributo de probabilidade. Analisados os usos e os atributos definidores dos conceitos de "débito cardíaco diminuído" e "risco", seus eventos antecedentes e consequentes, construiu-se a definição de risco de débito cardíaco diminuído, que foi validada por $100 \%$ dos especialistas. Conclusão: os dados obtidos permitiram inferir que o fenômeno risco de débito cardíaco diminuído pode se constituir num diagnóstico de enfermagem e, por meio do seu refinamento, contribuir para o avanço das classificações de enfermagem nesse contexto.

Descritores: Diagnóstico de Enfermagem; Débito Cardíaco; Risco; Formação de Conceito.

\section{Validación del concepto riesgo de débito cardiaco disminuido}

Objetivo: Validar el concepto riesgo del débito cardíaco disminuido. Método: Fue adoptada la técnica de Walker \& Avant para analizar la definición del fenómeno enfocado, utilizando seis de las ocho etapas sugeridas y la propuesta de Hoskins para validar el contenido, considerándose la conformidad entre cinco expertos. Resultados: el concepto de debito cardíaco disminuido se encuentra en las áreas enfermería y médica y su atención se centra en la capacidad de bombeo del corazón. Sin embargo, el concepto de riesgo es presente en un gran número de áreas. Las características definitorias de la disminución del gasto cardíaco mostraron como principal atributo deficiencia de la bomba cardiaca y, para el riesgo, el atributo de probabilidad. Analizados los usos y características definidoras de los conceptos "débito cardíaco disminuido" y "riesgo" con los hechos anteriores y subsiguientes, fue posible elaborar la definición de "riesgo de débito cardíaco disminuido", la cual fue validada por 100\% de los expertos. Conclusión: Los resultados encontrados permitieron concluir que el fenómeno de riesgo de débito cardíaco disminuido puede constituir un diagnóstico de enfermería y su refinamiento puede contribuir al avance de las clasificaciones de enfermería.

Descriptores: Diagnóstico de Enfermería; Débito Cardiaco; Riesgo; Formación de Concepto.

\section{Introduction}

Nursing diagnoses are essential in the nursing process because they represent the scientific interpretation of data collected for the clinical assessment of patients and support the planning, implementation and evaluation of nursing care.

Nursing diagnoses (NDx) are defined as the clinical judgment of nurses based on the responses of an individual, family, or community to certain real or potential vital processes. NDx began to be classified in standardized language by the North American Nursing Diagnosis Association (NANDA) in the 1970s and are constantly refined by NANDA International (NANDA I). Nursing researchers around the world have made efforts to improve them by creating, validating and submitting NDx ${ }^{(1)}$.
The use of the classification of NDx in clinical practice encourages the refinement and validation of the patient's health condition (individual/family/community) that exists in these nomenclatures and also for others not yet included in these structures.

An analysis of the NANDA I Taxonomy up to the version 2009-2011 shows that "risk for decreased cardiac output" is not described as a nursing diagnosis even though its guiding axes enable it to be established based on the diagnosis of "decreased cardiac output," which has been included in this classification since $1975^{(1)}$

Nurses are responsible for identifying individuals at risk and protecting them. A nursing diagnosis of risk is 
defined as a description of human responses to health conditions and/or vital processes that may develop in vulnerable individuals ${ }^{(1)}$.

The risk for decreased cardiac output is described as a nursing phenomenon in various studies, particularly for the population of clinical cardiac, surgical and critical patients(2-4).

The fact that decreased cardiac output is observed in the clinical practice of nurses but is not included in the NANDA I classification of diagnoses reinforces the need for this study, the objective of which is to propose a new diagnosis. Based on this evidence, the following question emerged: can the risk for decreased cardiac output be considered a nursing diagnosis?

The first step recommended to answer this question is to identify and analyze the concept through a systematic method that opens a perspective including other types of validation.

This study can contribute to the advancement in the subject since this diagnosis is seldom explored in studies conducted in the nursing field and NANDA is considering it for potential inclusion in its classification.

\section{Objectives}

To validate the concept of decreased cardiac output.

\section{Method}

Study developed in two phases: analysis and validation of the concept decreased cardiac output.

\section{Concept analysis}

This stage was developed between 2006 and 2012 using six of the eight steps suggested in the technique described by Walker \& Avant( ${ }^{(5)}$ : selection of conception, establishment of the analysis' objectives, identification of the concept's uses, establishment of defining attributes, identification of antecedent and consequent events and definition of empirical references. These six steps were chosen because the study is limited to the construction of a definition and its validation, which can be achieved with this proposal.

- Selection of the concept: the concept "risk for decreased cardiac output" was selected based on the authors' experience, which was confirmed by reports in the literature.

- Establishment of the analysis' objectives: to clarify the meaning of this phenomenon in the literature and also develop and validate a conceptual definition.

- Identification of the concept's uses: it is suggested to identify as large a variety of applications of the concept as possible and consider them all, avoiding a skewed understanding of its nature and the limitation of its use in the analysis' results. A broad search was performed covering the last 15 years (Jan 1997 to Jan 2012) due to the need to encompass the largest number of studies addressing the subject. The key words used were: nursing diagnosis, risk, decreased cardiac output.

We performed both electronic and manual bibliographic searches. The databases included: Medical Literature Analysis and Retrieval System Online (MEDLINE), Latin American and Caribbean Center on Health Sciences (LILACS), Bibliographic Database of the University of São Paulo (DEDALUS) and Scientific Electronic Library Online (SCIELO). The search in introductory literature, textbooks in physiology, physiopathology and the classification of NDx NANDA I theses, dissertations and dictionaries, was performed in the libraries of the Federal University of São Paulo and the University of São Paulo. A total of 32 papers and texts were found, of which 19 were selected. We developed an instrument to collect data that addressed the definition of "decreased cardiac output", its manifestations and causes, and the definition of the term "risk".

- Determination of the (critical) defining attributes: we opted to identify the defining attributes of the concepts related to "decreased cardiac output" and "risk" separately in order to discriminate what is and what is not an expression of the concept under study.

- Identification of antecedents and consequent events of the risk for decreased cardiac output: based on the literature, we answer the following question in order to identify the antecedent events: what conditions/ behaviors contribute to the occurrence of this concept? To identify the consequent events we began with the following question: what situations/reactions can result in the verification of this phenomenon?

A conceptual definition of "Risk for decrease cardiac output" was established after this stage and was submitted to content validation.

- Definition of empirical references: this is the final step of the concept's analysis in which the purpose is to identify empirical references that are categories or classes of observable phenomena, which, when present, evidence the occurrence of this event.

\section{Content validation of the definition of "risk for decreased cardiac output"}

The proposal made by Hoskins( ${ }^{(6)}$ was used in this phase. Her proposal is focused on the judgment of a 
group of experts. She emphasizes that there was no mention, in the literature, concerning a specific number of specialists to validate a nursing diagnosis.

The selection of experts is currently considered a critical point in validation studies due to a lack of uniformity in choice criteria. The difficulties faced are generally related to the individuals' academic degrees, specialized knowledge and sample size, which may be related to the availability, or the lack of availability, of professionals with the required competence and representativeness desired(7). Hence, only five experts were included due to the difficulty of finding nurses with the required expertise at the time of data collection.

Criteria for the selection of experts included: nurses with a doctorate in the line of research of cardiologic nursing and clinical experience of at least ten years in the field. Given the fact that decreased cardiac output is a subject already widely explored in the medical field and due to the difficulty of finding nurses with the necessary skills in the city of São Paulo, Brazil and also given the diagnosis' characteristics, we opted to select a group of cardiologists who met the same selection criteria as the nurses. Having physician experts to validate the concept of decreased cardiac output was not considered an impediment since the characteristics of this NDx are basically of a physiological nature and refer to conditions widely explored in the medical field.

- Data collection: the authors developed an instrument addressing two items: the definition of risk for decreased cardiac output proposed after a preliminary analysis of the concept and verification of agreement and coherence of the definition with its label. Both had the following answer options: "Yes", with a blank space to add comments and "No", with a blank space to add a justification.

The study's project was approved by the Institutional Review Board at the Federal University of São Paulo (Process No. 0095/05) and the experts signed free and informed consent forms.

- Data analysis: was descriptive, based on inter-rater agreement and disagreement. It was established that the definition would be considered valid only if a consensus of $75 \%$ was reached among the judges.

\section{Results}

The results are presented in two topics: analysis of concept and content validation of the definition of risk for decreased cardiac output.

\section{Concept analysis}

- Concept selection: the selection of the concept "decreased cardiac output" was a simple process since it was already an object of study, as well as a phenomenon observed in the clinical practice of nurses.

- Establishment of analysis' objectives: the concept analysis of the terms 'risk' and 'decreased cardiac output' had the single purpose of proposing a definition for the NDx 'Risk for decreased cardiac output'.

- Identification of the concept's uses: a bibliographic search showed that "risk for decreased cardiac output", expressed in this way, is a concept not described in Nursing Classifications and seldom explored in publications in the medical field. Consequently, we opted to break down the concept "risk for decreased cardiac output" into "decreased cardiac output' and "risk," since both are concepts presented in the literature.

The concept "decreased cardiac output" was only found in medical and nursing literature and refers to heart pumping capacity, as some of the main definitions found in the literature show: insufficient quantity of blood pumped by the heart to meet the body's metabolic needs $^{(1)}$; cardiac output falls below its required level(8); state in which the individual shows a reduction in quantity of blood pumped by the heart, resulting in impaired cardiac function(9); state in which the quantity of blood pumped by an individual's heart is inadequate to meet the needs of body tissues ${ }^{(10)}$; and, heart's inability to pump sufficient blood flow to meet tissues' metabolic needs ${ }^{(11)}$.

The use of the concept "risk", in turn, is present in a large number of disciplines, such as Geology, Economics, Administration, Engineering, Ecology and Environmental Sciences, Sociology, Psychology, Law, and Communication. Nonetheless, the interest of this study was in the concepts found in the health field where risk was expressed as: the measure of occurrences of new cases of the disease under study among the population(12); cumulative incidence or likelihood of a disease, injury, death or condition related to the health of a population or group of individuals, during a certain period of time(13); potential danger of an adverse reaction among people exposed to $i^{(14)}$; possibility of damage in various dimensions of the human being, such as the physical, psychological, moral, intellectual, social, cultural or spiritual dimensions(15); and the likelihood of an unfavorable outcome, injury or unwanted phenomenon $^{(16-17)}$. 
- Establishment of the defining attributes (critical attributes): since the risk for decreased cardiac output is not described in the literature, we could not identify the characteristics that enable a differential diagnosis in order to discriminate what is and what is not an expression of the study's concept.

As previously mentioned, we opted to break up the analysis of the concept and obtain the defining attributes of the concepts related to "decreased cardiac output" and "risk" separately.

The attributes of decreased cardiac output were described as: inadequate quantity, insufficient or reduced quantity of blood pumped by heart and also, heart impairment ${ }^{(1,8-11)}$.

After analyzing each of these attributes of decreased cardiac output, we concluded that "impaired cardiac output" expresses the concept under study well.

The main defining attributes of risk identified were: likelihood or possibility of events, failures or harm to occur, potential danger, cumulative incidence, objective threat, probabilistic association, quantitative expression, measure or statistical probability of occurrence(12-17).

After analyzing the meaning of these attributes, we consider the term "predisposition" to be appropriate, which is defined as a disposition to contract certain pathological states ${ }^{(18)}$, to define the condition of risk for decreased cardiac output, instead of probability or incidence, each of which assume a longitudinal prospective epidemiological study ${ }^{(12-13)}$.

After analyzing the attributes of decreased cardiac output and risk, we reached the conceptual definition of risk for decreased cardiac output: "state in which the individual presents factors that predispose him/her to a decreased quantity of blood pumped by heart to meet his/her metabolic needs."

- Identification of antecedent and consequent events of the concept "risk for decreased cardiac output": the response to the question "what events contribute to the occurrence of the phenomenon of risk for decreased cardiac output?"; that is, "what are this phenomenon's antecedents?" we have "any conditions that change the determinants of cardiac output - preload, afterload, heart rate, and contractility - can reduce it" (8,19-20).

The consequents of the concept refer to events or situations that result from the risk for decreased cardiac output, which are apparent in the effective application of the concept in clinical practice. For the answer to the question "what can happen after the condition of risk for decreased cardiac output is established?", or, what the consequents of this phenomenon are, we have "if preventive interventions are not implemented early, one may face a risk situation of a real condition of decreased cardiac output, where the quantity of blood pumped by heart is insufficient to meet one's metabolic demands"(1).

Reactions observed in this situation correspond, according to the Nursing Diagnoses Classifications NANDA I ${ }^{(1)}$, to the defining characteristics, which are the signs and symptoms that derive after the phenomenon is established, such as agitation, low ejection fraction, arrhythmias, dyspnea, oliguria, and edema, among others.

- Definition of empirical references: the identified empirical references correspond to factors (causes) related to decreased cardiac output in the diagnostic structure of the Classification of Nursing Diagnoses - NANDA I, which are changes in contractility, heart rate, preload, afterload, and ejection fraction. Keeping in mind that there are various factors that can change these determinants, e.g. myocardial dysfunction, blood loss, increased intrapericardial pressure, change in heart rhythm or electrical conduction of the heart, deficient fluid volume, loss of plasma, ineffective tissue perfusion, electrolyte imbalance, acid-base imbalance, and valve alterations, among others ${ }^{(21)}$.

Future studies can help to validate these and other empirical references as risk factors for the phenomenon under study (risk for decreased cardiac output), as well as the development of conceptual and operational definitions for it, which will help the identification of these phenomena by nurses.

\section{Content validation of the definition "risk for decreased cardiac output"}

This process resulted in $100 \%$ agreement among the experts concerning the definition established for risk of decreased cardiac output and also concerning the coherence and consistency of the definition in relation to its title. Some of the judges' suggestions to broaden the definition were accepted, which resulted in: state in which the individual presents factors that predispose the individual to a reduced quantity of blood pumped per minute by the heart to the body to meet one's metabolic needs.

Due to $100 \%$ agreement among the experts and the fact that the changes suggested do not change the core of the definition, we deemed implementing another evaluation to be unnecessary.

\section{Discussion}

The conceptual exploration of the studied phenomenon and its validated definition is one step 
closer to linking it to practice. Scientific investigations deal with concepts and a lack of theoretical definition and careful operationalization impede the results of studies from contributing to nursing knowledge.

Analysis of concept is recommended as an efficient way to carry on some phases in the progress of scientific development. Nursing concepts are those that capture or represent phenomena in the nursing domain and nursing diagnoses are a specific sub-classification of these concepts. Each nursing diagnosis has a definition that characterizes it as such, representing, therefore, a concept $^{(22)}$.

It is worth noting that a concept is created based on a multiplicity of situations and within these different visions it acquires meanings according to what is experienced, since creating concepts is to produce reality(23).

In relation to the studied concepts, while decreased cardiac output was only found in in medical and nursing literature(1,8-11), the concept 'risk' is nomadic and guides many practices receiving diverse content according to different fields of knowledge ${ }^{(24}$.

In regard to "risk", its defining/critical attribute was "the probability of an event occurring in the future(16), largely some potential harm or danger ${ }^{(13,17)}$." This descriptor, however, should not always be associated with a negative context because it can be related to something positive, such as the possibility of foreseeing what can go wrong in the future(24), or the promotion of actions aimed to avoid such risks, glimpsing the possibility of obtaining gains, not only losses(25).

The attribute "probability" appears frequently when one wants to define this concept and its definition is a "favorable perspective that something will happen or the degree of safety one can expect from an event, determined by the relative frequency of events of the same type in a series of attempts. Mathematically, it is considered a positive number, ranging from zero to one, associated with a random event measured by the relative frequency of its occurrence in a long succession of events ${ }^{(18)}$. We perceive that the attributes: measure of occurrence, cumulative incidence, possibility of harm, possibility of occurrence, and quantitative expression, are related to the attribute probability.

Other attributes found for the concept "risk" were "danger" and "objective threat". The attribute "danger" or "potential danger" is defined as a situation in which the existence or integrity of a person is being threatened, that is, there is a risk, since the term "potential" designates possibility ${ }^{(18)}$.
In regard to decreased cardiac output, this is a concept established in the medical literature as a sign or symptom of a disease and in nursing as a diagnosis, with the definition, characteristics and related factors, established in NANDA - $\mathrm{I}^{(1)}$ in 1975 and revised in 1996 and 2000. This NDx is widely explored in studies in the field, resulting in vast knowledge, both in terms of its defining characteristics and related factors ${ }^{(26)}$, since the main definition for this phenomenon is of the aforementioned classification of diagnoses.

The concept "deficit in the amount of blood pumped by heart" suggested in this study's results as a reconciler of others such as inadequate quantity, insufficient or reduced volume of blood pumped by heart, is well supported in the literature ${ }^{(1,8-11)}$.

It is worth noting that no studies were found in the nursing literature addressing the analysis and validation of the concept "risk for decreased cardiac output" and this study provides a preliminary contribution to the proposal of a conceptual definition based on the exploration of defining attributes of the concepts 'risk' and 'decreased cardiac output,' validated by experts.

The definition for the risk for decreased cardiac output phenomenon found in another study was solely based on the literature and not on conceptual analysis, a prerequisite for creating a new concept. The study presented the following definition for this phenomenon "to be in risk of developing a level of health characterized by insufficient quantity of blood pumped each minute by the heart to fulfill the physical metabolic demands."(21)

In the analysis of the definition suggested above, we draw attention to the use of the word "risk", reaffirming what is explicit in the title, and also to the presence of the term "characterized", which refers to defining characteristics used in the NANDA I classification, defined as observable evidence or inferences of a real NDx, of wellbeing or health promotion ${ }^{(1)}$.

Despite this study's limitations, i.e. conceptual analysis of six phases instead of the eight originally suggested, which restricts the definition of the phenomenon, and the small sample of experts, it permits one to glimpse "risk for decreased cardiac output" as a nursing diagnosis, since decreased cardiac output has been already established in NANDA - $\mathrm{I}^{(1)}$. We note that with the axes of evaluation of nursing classifications, when there is a real diagnosis, there is also the possibility of developing a risk diagnosis, based on the assumption that factors related to a real diagnosis can be considered risk factors for the same situation previously established.

After completing the conceptual analysis of the 
phenomenon 'risk for decreased cardiac output' and establishing and validating its definition, this diagnosis was submitted to the Classification of Nursing Diagnoses NANDA - I for scrutiny and potential addition in its list of approved diagnostics.

\section{Conclusion}

The selection of the concept risk for decreased cardiac output was considered simple because it is a phenomenon observed in nurses' clinical practice.

The concept of decreased cardiac output was found in the nursing and medical fields and is focused on heart pumping capacity. In turn, the concept "risk" is present in a large number of disciplines such as Law, Geology, Economic, Business Administration, Engineering, and Sociology, among others.

In regard to the defining attributes, the main attribute of decreased cardiac output was "impaired pumping capacity," while the main attribute of risk was "probability".

The antecedents of decreased cardiac output, that is, the situations of risk, are considered any conditions that change preload, afterload, heart rate, and contractility, since its consequent is the situation of decreased cardiac output already established with its signs and symptoms (defining characteristics) described by NANDA - I. The empirical references found include: myocardial dysfunction, blood loss, increased intrapericardial pressure, change in heart rhythm or electrical conduction of heart, deficient fluid volume, loss of plasma, ineffective tissue perfusion, electrolyte imbalance, acid-base imbalance, and valve alterations, among others ${ }^{(21)}$.

The risk of decreased cardiac output is a concept acknowledged as a component of nursing practice that still requires further support.

The analysis of association of its critical attributes, represented by the terms "risk" and "decreased cardiac output" enabled the establishment of the conceptual definition of the phenomenon under study, which was considered valid by $100 \%$ of the experts.

This is a preliminary assessment that requires replication with a larger number of experts but is a step towards its continuity and refinement with the selection and definition of its empirical references represented by risk factors that will later ground two types of validation: broader conceptual validation and clinical validation.

Therefore, we assume that from the moment at which the concept "risk for decreased cardiac output" was clarified and validated, it becomes applicable in the health context and enables new directions for the development of studies seeking to refine it as a nursing diagnosis.

\section{References}

1. NANDA (North American Nursing Diagnosis Association). Nursing Diagnosis: definitions \& classification 2003-2004. Philadelphia: NANDA International; 2013. 606 p.

2. Suriano MLF, Barros ALBL. Identification of the most frequently nursing diagnoses in the perioperative period of patients udergoing cardiovascular surgery. Acta Paul Enferm. 2000;13(spec number, Part 2):99-104.

3. Silva RCG, Cruz DALM. Identificação dos diagnósticos de enfermagem, características definidoras e fatores de risco em pacientes valvopatas. Rev Soc Cardiol Estado de São Paulo. 2002;2(Supl A):1-7.

4. Lima LR, Pereira SVM. Diagnósticos de enfermagem em pacientes pós - cateterismo cardíaco: uma contribuição de Orem. Rev Bras Enferm. 2006;59(3):285-90.

5. Walker LO, Avant KC. Concept development. In: Walker LO, Avant KC. Strategies for theory construction in nursing. 5rd ed. Norwalk: Appleton \& Lange; 2010. p. 109-21.

6. Hoskins LM. Clinical validation, methodologies for nursing diagnoses research. In: Johnson RMC. Classification of nursing diagnosis: proceedings of the eighth Conference. Philadelphia: Lippincott; 1989. p. 116-32.

7. Carvalho EC, Mello AS, Napoleão AA, Bachion MM, Dalri MCB, Canini SRMS. Validação de diagnóstico de enfermagem: reflexão sobre dificuldades enfrentadas por pesquisadores. Revista Eletrônica de Enfermagem. [periódico na Internet]. 2008; [acesso 10 set 2011]. 10(1):235-40. Disponível em: http://www.fen.ufg.br/ revista/v10/n1/v10n1a22.htm.

8. Guglin M. Key role of congestion in natural history of heart failure. Int J Gen Med. 2011;4:585-91.

9. Carpenito-Moyet LJ. Manual de diagnóstico de enfermagem. 13a ed. Porto Alegre: Artmed; 2011. 1028 p. 10. Benedet SA, Bub MBC. Manual de diagnóstico de enfermagem, 2a ed. São Paulo: Bernúcia; 2000. 189 p. 11. Vela JLP, Benítez JCM, González MC, De La Cal López MA, Pérez RH, Meneses VS et al. Guías de práctica clínica para el manejo del síndrome de bajo gasto cardíaco en el postoperatorio de cirurgia cardíaca. Med Intensiva. 2012;36(4):e1-e44.

12. Ayres, JRCM. Desenvolvimento histórico- 
epistemológico da epidemiologia e do conceito risco. Cad Saúde Pública. 2011;27(7):1301-11.

13. Almeida N Filho, Coutinho D. Causalidade, contingência, complexidade: o futuro do conceito de risco. Physis: Rev Saúde Coletiva. 2007;17(1):95-137.

14. Cox LA Jr. Risk analysis: foundations, models and methods. Boston: Kluwer; 2002. 568 p.

15. Resolução CNS 196/96 (BR). Resolução Nacional de saúde. Resolução n. 196/96 Sobre pesquisa envolvendo seres humanos. Diário Oficial da União, 16 out 1996:21082-5.

16. Coutinho ESF, Cunha GM. Conceitos básicos de epidemiologia e estatística para a leitura de ensaios clínicos controlados. Rev Bras Psiquiatr. $2005 ; 27(2): 146-51$.

17. Althaus CE. A disciplinary perspective on the epistemological status of risk. Risk Anal. $2005 ; 25(3): 567-88$.

18. Houaiss A, Villar MS, Franco FMM. Houaiss da língua portuguesa. Rio de Janeiro: Objetiva; 2004. 3008 p.

19. Eillis MF. Low cardiac output following cardiac surgery: critical thinking steps. Dimensions Crit Care Nurs. 1997;16(1):48-55.

20. Hollenberg SM. Recognition and treatment of cardiogenic shock. Semin Respir Crit Care Med. $2004 ; 25(6): 661-71$.

21. Melo RP, Lopes MVOL, Araújo TL, Silva FS, Santos FAAS, Moorhead S. Risk for decreased cardiac output: validation of a proposal for nursing diagnosis. Nurs Crit Care. 2011;16(6):287-94.

22. Creason NS, Camilleri DD, Kim MJ. Concept development in nursing diagnosis. In: Rodgers $\mathrm{BL}, \mathrm{Knafl}$ KA. Concept development in nursing. Philadelphia: WB Saunders; 1993. p. 217-34.

23. Freitas MC, Mendes MMR. Concept dimension for nursing and Deleuze. Rev. Latino-Am. Enfermagem. 2004;12(1):128-33.

24. Guzzo M. Corpo em Risco. Athenea Digital [Internet]. 2004. [acesso 10 set 2011]; 6:56-65 Disponível em: http://antalaya.uab.es/athenea/num6/guzzo.pdf.

25. Spink MJP, Medrado B, Mello RP. Perigo, probabilidade e oportunidade: a linguagem dos riscos na mídia. Psicol Reflex Crit. 2002;15(1):151-64.
26. Matos LN, Guimaraes TCF; Brandao MAG, Santoro DC. Prevalence of nursing diagnosis of decreased cardiac output and the predictive value of defining characteristics in patients under evaluation for heart transplant. Rev. Latino-Am. Enfermagem [periódico na Internet]. 2012 [acesso 29 out 2012]; 20(2):307-15 . Disponível em: $\quad$ http://www.scielo.br/scielo.php?script=sci_ arttext\&pid =S0104-11692012000200013\&Ing=en\&nr $\mathrm{m}=\mathrm{iso}>$. ISSN 0104-1169. http://dx.doi.org/10.1590/ S0104-11692012000200013. 